\title{
ON ONE SOBOLEV TYPE MATHEMATICAL MODEL IN QUASI-BANACH SPACES
}

\author{
A.A. Zamyshlyaeva, South Ural State University, Chelyabinsk, Russian Federation, \\ alzama@mail.ru, \\ H.M. Al Helli, South Ural State University, Chelyabinsk, Russian Federation
}

\begin{abstract}
The theory of Sobolev type equations experiences an epoch of blossoming. In this article the theory of higher order Sobolev type equations with relatively spectrally bounded operator pencils, previously developed in Banach spaces, is transferred to quasi-Banach spaces. We use already well proved for solving Sobolev type equations phase space method, consisting in reduction of singular equation to regular one defined on some subspace of initial space. The propagators and the phase space of complete higher order Sobolev type equations are constructed. Abstract results are illustrated by specific examples. The Boussinesq-Love equation in quasi-Banach space is considered as application.
\end{abstract}

Keywords: Sobolev type equations; quasi-Banach spaces; propagators; phase space.

Introduction. Let $\mathfrak{U}, \mathfrak{F}$ be Banach spaces, operators $L, M \in \mathcal{L}(\mathfrak{U} ; \mathfrak{F})$ (i.e. linear, continuous, defined on $\mathfrak{U}$ and acting into $\mathfrak{F}$ ). Consider a Sobolev type equation (the term was introduced by R.E. Showalter [1])

$$
A u^{\prime \prime}=B_{1} u^{\prime}+B_{0} u, \text { ker } A \neq\{0\} .
$$

Sobolev type equations have been already well researched. The first monograph devoted to such equations was published in 2003 [2]. Here degenerate analytical (semi)group, and degenerate $C_{0}$-semigroups used in the study of equations of the first order were constructed. Linear Sobolev type equations of higher order in Banach spaces were studied in [3]. The results of Sobolev type equations theory are used in the theory of dynamical measurements [4], optimal control theory [5, 6], in the study of dichotomies of equations of the form (1) $[7,8]$. In addition, the theory of degenerate groups and semigroups of operators was transferred into a locally convex spaces.

Equations that are not solved with respect to the highest derivative in time were studied for the first time by A. Poincare, however, a systematic study of them was started in the middle of the last century after the fundamental work of S.L. Sobolev. Now the Sobolev type equations theory is actively studied area of nonclassical equations of mathematical physics, and a number of monographs, completely devoted to them, or in part, is growing like an avalanche.

In this paper Sobolev type equations of the second order of the form (1) are considered in quasi-Banach spaces. As it is well known [9, p. 3.10], a quasi-Banach space is not a normed one, but it can be made metrizable. One of the examples of a quasi-Banach space is a space of sequences $\ell_{q}, q \in(0,1)$. In [10] there was constructed a quasi-Banach space $\ell_{q}^{m}, q \in(0,1), m \in \mathbb{R}, \ell_{q}^{0}=\ell_{q}$ which was called a quasi-Sobolev space. These spaces we will be used to illustrate the abstract results of the paper.

The authors consider it their pleasant duty to express there sincere gratitude to Professor G. A. Sviridyuk for the statement of the problem and fruitful discussions.

1. Relatively Bounded Operator Pencils in Quasi-Banach Spaces. A lineal $\mathfrak{U}$ over a field $\mathbb{R}$ is called a quasi-normed, if there is a function $\mathfrak{u}\|\cdot\|: \mathfrak{U} \rightarrow \mathbb{R}$ with the following properties:

(i) $\mathfrak{U}\|u\| \geq 0$ for all $u \in \mathfrak{U}$, and $\mathfrak{U}\|u\|=0$ exactly when $u=\mathbf{0}$, where $\mathbf{0}$ is a zero in lineal $\mathfrak{U}$; 
(ii) $\mathfrak{U}\|\alpha u\|=|\alpha|_{\mathfrak{U}}\|u\|$ for all $u \in \mathfrak{U}, \alpha \in \mathbb{R}$;

(iii) $\mathfrak{U}\|u+v\| \leq C(\mathfrak{u}\|u\|+\mathfrak{U}\|v\|)$ for all $u, v \in \mathfrak{U}$, where the constant $C \geq 1$.

A function $\mathfrak{u}\|\cdot\|$ with properties (i) - (iii) is called a quasi-norm. In particular, if $C=1$ a quasi-norm $\mathfrak{U}\|\cdot\|$ is called a norm, and lineal $\mathfrak{U}$ with the norm $\mathfrak{U}\|\cdot\|$ is a normed one. A quasi-normed lineal $(\mathfrak{U} ; \mathfrak{u}\|\cdot\|)$ is metrizable (see [9, Lemma 3.10.1]), so we have a conception of the fundamental (or Cauchy) sequence $\left\{u_{k}\right\} \subset \mathfrak{U}: \mathfrak{u}\left\|u_{k}-u_{l}\right\| \rightarrow 0$ for $k, l \rightarrow \infty$. Define the quasi-Banach space as a full quasi-normed lineal.

Example 1. Let $\left\{\lambda_{k}\right\} \subset \mathbb{R}_{+}$be a monotonic sequence such that $\lim _{k \rightarrow \infty} \lambda_{k}=+\infty$, and $q \in \mathbb{R}_{+}$. Put

$$
\ell_{q}^{m}=\left\{u=\left\{u_{k}\right\} \subset \mathbb{R}: \sum_{k=1}^{\infty}\left(\lambda_{k}^{\frac{m}{2}}\left|u_{k}\right|\right)^{q}<+\infty\right\} .
$$

Lineal $\ell_{q}^{m}$ for all $m \in \mathbb{R}, q \in \mathbb{R}_{+}$with a quasi-norm of element $u=\left\{u_{k}\right\} \in \ell_{q}^{m}$

$$
{ }_{q}^{m}\|u\|=\left(\sum_{k=1}^{\infty}\left(\lambda_{k}^{\frac{m}{2}}\left|u_{k}\right|\right)^{q}\right)^{1 / q}
$$

is a quasi-Banach space (for $q \in[1,+\infty)$ it is a Banach space). Note that if $q \in(0,1)$, then constant $C=2^{1 / q}$ in (iii). The spaces $\ell_{q}^{m}$ are called quasi-Sobolev in [10].

Let $\mathfrak{U} ; \mathfrak{U}\|\cdot\|)$ and $(\mathfrak{F} ; \mathfrak{F}\|\cdot\|)$ be quasi-Banach spaces, a linear operator $L: \mathfrak{U} \rightarrow \mathfrak{F}$ with the domain $\operatorname{dom} L=\mathfrak{U}$ is called continuous if $\lim _{k \rightarrow \infty} L u_{k}=L\left(\lim _{k \rightarrow \infty} u_{k}\right)$ for any the sequence $\left\{u_{k}\right\} \subset \mathfrak{U}$ which is convergent in $\mathfrak{U}$. Note that in this case the linear operator $L: \mathfrak{U} \rightarrow \mathfrak{F}$ is continuous precisely when it is bounded (i.e., displays bonded sets to bounded sets). Denote by $\mathcal{L}(\mathfrak{U} ; \mathfrak{F})$ a lineal (over the field $\mathbb{R}$ ) of linear bounded operators. It is a quasiBanach space with quasi-norm

$$
\mathcal{L}(\mathfrak{U} ; \mathfrak{F})\|L\|=\sup _{\mathfrak{L}\|u\|=1} \mathfrak{F}\|L u\| .
$$

Now let the operators $A, B_{1}, B_{0} \in \mathcal{L}(\mathfrak{U} ; \mathfrak{F})$. Following [3], introduce the sets $\rho^{A}(\vec{B})=$ $\left\{\mu \in C:\left(\mu^{2} A-\mu B_{1}-B_{0}\right)^{-1} \in \mathcal{L}(\mathfrak{F} ; \mathfrak{U})\right\}$ and $\sigma^{A}(\vec{B})=C \backslash \rho^{A}(\vec{B})$, which are called an $A$-resolvent set and an $A$-spectrum of the pencil $\vec{B}$, respectively.

The operator-function $R_{\mu}^{A}(\vec{B})=\left(\mu^{2} A-\mu B_{1}-B_{0}\right)^{-1}$ with domain $\rho^{A}(\vec{B})$ is called an A-resolvent of pencil $\vec{B}$.

Definition 1. A pencil of operators $\vec{B}$ is called polynomially relatively bounded with respect to operator $A$ (or polynomially A-bounded) if

$$
\exists a \in R_{+} \forall \mu \in C(|\mu|>a) \Rightarrow\left(R_{\mu}^{A}(\vec{B}) \in \mathcal{L}(\mathfrak{F} ; \mathfrak{U})\right) .
$$

Fix $\gamma=\{\mu \in C: / \mu \mid=r>a\}$ which is a contour bounding a disk containing $\sigma^{A}(\vec{B})$. We require additional condition

$$
\int_{\gamma} R_{M}^{A}(\vec{B}) d \mu=0
$$

This condition was introduced in [3] and is very important in considering of the Sobolev type equations of higher order. Note that if there exists an operator $A^{-1} \in \mathcal{L}(\mathfrak{F} ; \mathfrak{U})$ or operator $B_{1}=\mathbb{O}$ (equation is incomplete), then condition $(A)$ holds; and if operator $A=\mathbb{O}$ and there exists an operator $B_{1}^{-1} \in \mathcal{L}(\mathfrak{F} ; \mathfrak{U})$, then condition $(A)$ is not fulfilled. 
Let the pencil $\vec{B}$ be polynomially $A$ bounded, and (A) be fulfilled. Then there exist the following integrals of analytic operator functions:

$$
P=\frac{1}{2 \pi i} \int_{\gamma} \mu R_{\mu}^{A}(\vec{B}) A d \mu, Q=\frac{1}{2 \pi i} \int_{\gamma} \mu A R_{\mu}^{A}(\vec{B}) d \mu .
$$

Lemma 1. Let the pencil $\vec{B}$ be polynomially A-bounded and (A) be fulfilled.Then the operators $P \in \mathcal{L}(\mathfrak{U})$ and $Q \in \mathcal{L}(\mathfrak{F})$ are projectors.

Denote $\mathfrak{U}^{0}=\operatorname{ker} P, \mathfrak{F}^{0}=\operatorname{ker} Q, \mathfrak{U}^{1}=\operatorname{im} P, \mathfrak{F}^{1}=\operatorname{im} Q$. By lemma $\mathfrak{U}=\mathfrak{U}^{0} \oplus \mathfrak{U}^{1}, \mathfrak{F}=$ $\mathfrak{F}^{0} \oplus \mathfrak{F}^{1}$. By $A^{k}\left(B_{l}^{k}\right)$ denote restriction of operator $A\left(B_{l}\right)$ onto $\mathfrak{U}^{k}, k, l=0,1$.

Theorem 1. Let the pencil $\vec{B}$ be polynomially $A$ bounded, and (A) be fulfilled. Then actions of operators split:

(i) $A^{k} \in \mathcal{L}\left(\mathfrak{U}^{k} ; \mathfrak{F}^{k}\right), k=0,1$

(ii) $B_{l}^{k} \in \mathcal{L}\left(\mathfrak{U}^{k} ; \mathfrak{F}^{k}\right), k, l=0,1$;

(iii) there exists an operator $\left(A^{1}\right)^{-1} \in \mathcal{L}\left(\mathfrak{F}^{1} ; \mathfrak{U}^{1}\right)$;

(iv) there exists an operator $\left(B_{0}^{0}\right)^{-1} \in \mathcal{L}\left(\mathfrak{F}^{0} ; \mathfrak{U}^{0}\right)$.

Example 2. Using formula $\Lambda u=\left\{\lambda_{k} u_{k}\right\}, u \in \ell_{q}^{m}$ we introduce a Laplace quasi-operator. It is easy to show [10] that operator $\Lambda: \ell_{q}^{m+2} \rightarrow \ell_{q}^{m}$ is a toplinear isomorphism for all $m \in \mathbb{R}, q \in \mathbb{R}_{+}$. The inverse operator $\Lambda^{-1} u=\left\{\lambda_{k}^{-1} u_{k}\right\}$ is called a Green quasi-operator.

Next, construct the operators $A=\lambda-\Lambda$ and $B_{1}=\alpha\left(\Lambda-\lambda^{\prime}\right), B_{0}=\beta\left(\Lambda-\lambda^{\prime \prime}\right)$ $\alpha, \beta \in \mathbb{R}_{+}$.

\section{Lemma 2. Let}

(i) $\lambda \notin\left\{\lambda_{k}\right\}$ or (ii) $\left(\lambda \in\left\{\lambda_{k}\right\}\right) \wedge\left(\lambda \neq \lambda^{\prime}\right)$. Then the pencil $\vec{B}=\left(B_{1}, B_{0}\right)$ is polynomially $A$-bounded, moreover, $\infty$ is a removable singularity of $A$-resolvent of $\vec{B}$.

(iii) $\left(\lambda \in\left\{\lambda_{k}\right\}\right) \wedge\left(\lambda=\lambda^{\prime}\right) \wedge\left(\lambda \neq \lambda^{\prime \prime}\right)$. Then the pencil $\vec{B}=\left(B_{1}, B_{0}\right)$ is polynomially $A$-bounded moreover, $\infty$ is a pole of order 1 of $A$-resolvent of $\vec{B}$.

Remark 1. In case (i) $A$-spectrum of pencil $\vec{B} \sigma^{A}(\vec{B})=\left\{\mu_{k}^{1,2}: k \in \mathbb{N}\right\}$, where $\mu_{k}^{1,2}$ are the roots of equation

$$
\left(\lambda-\lambda_{k}\right) \mu^{2}+\alpha\left(\lambda^{\prime}-\lambda_{k}\right) \mu+\beta\left(\lambda \lambda_{k}\right)=0
$$

In case (ii) $\sigma^{A}(\vec{B})=\left\{\mu_{k}^{1,2}: k \in \mathbb{N}, \lambda_{k} \neq \lambda\right\} \cup\left\{\mu_{l}: l \in \mathbb{N}, \lambda_{l}=\lambda\right\}$, where $\mu_{k}^{1,2}$ are the roots of (2) when $\lambda=\lambda_{k}$, and $\mu_{l}$ is the root of (2) when $\lambda=\lambda_{l}$. In case (iii) $\sigma^{A}(\vec{B})=\left\{\mu_{k}^{1,2}: k \in \mathbb{N}, \lambda_{k} \neq \lambda\right\}$.

Remark 2. It is easy to see that if $\left(\lambda \in\left\{\lambda_{k}\right\}\right) \wedge\left(\lambda=\lambda^{\prime}=\lambda^{\prime \prime}\right)$ then the pencil $\vec{B}$ is not polynomially $A$-bounded.

Now let's check the condition $(A)$. In case (i) there exists an operator $A^{-1} \in \mathcal{L}(\mathfrak{F} ; \mathfrak{U})$, so that condition $(A)$ holds. In case (ii)

$$
\frac{1}{2 \pi i} \int_{\gamma} \sum_{k=1}^{\infty} \frac{<\varphi_{k}, \cdot>\varphi_{k} d \mu}{\left(\lambda-\lambda_{k}\right) \mu^{2}+\alpha\left(\lambda^{\prime}-\lambda_{k}\right) \mu+\beta\left(\lambda \lambda_{k}\right)}=\sum_{\lambda=\lambda_{k}} \frac{<\varphi_{k}, \cdot>}{\alpha\left(\lambda^{\prime}-\lambda_{k}\right)} \varphi_{k} \neq 0,
$$

i.e. $(A)$ is not fulfilled, so this case is excluded from further considerations. In case (iii) (A) holds. 
2. The Phase Space and Propagators. Now consider the Sobolev type equation of the second order (1) with the initial condition

$$
u^{(m)}(t)=u(m, m=0,1 .
$$

Definition 2. The operator-function $\mathfrak{U}^{\bullet} \in C^{\infty}(\mathbb{R} ; \mathcal{L}(\mathfrak{U}))$ is called a propagator of equation (1) if for any $u \in \mathfrak{U}$ vector-function $u(t)=U^{t} u$ is a solution of this equation.

Lemma 3. Let the pencil $\vec{B}$ be polynomially A-bounded and condition $(A)$ be fulfilled. Then there exist propagators of equation (1):

$$
U_{1}^{t}=\frac{1}{2 \pi i} \int_{\gamma} R_{\mu}^{A}(\vec{B}) A e^{\mu t} d \mu, t \in \mathbb{R}, \quad U_{0}^{t}=\frac{1}{2 \pi i} \int_{\gamma} R_{\mu}^{A}(\vec{B})\left(\mu\left(A-B_{1}\right) e^{\mu t} d \mu, t \in \mathbb{R}\right.
$$

Further, if the pencil $\vec{B}$ is polynomially $A$-bounded, condition $(A)$ holds and $\infty$ is a pole of order $p \in\{0\} \cup \mathbb{N}$ of $A$-resolvent of $\vec{B}$, then the pencil $\vec{B}$ is called $(A, p)$-bounded.

Definition 3. The Set $\mathfrak{P} \subset \mathfrak{U}$ is called a phase space of equation (1) if

(i) for any $u_{j} \in \mathfrak{P}, j=0,1$, there exists a unique solution of (1), (3);

(ii) any solution $u=u(t)$ of equation (1) lies in $\mathfrak{P}$ as a trajectory (i.e., $u(t) \in \mathfrak{P}$ for all $t \in \mathbb{R})$.

Theorem 2. Let the operator $M$ be $(L, p)$-bounded, $p \in\{0\} \cup \mathbb{N}$. Then the subspace $\mathfrak{U}^{1}$ is a phase space of equation (1). Moreover, for any $u_{j} \in \mathfrak{U}^{1}, j=0,1$, there exists a unique solution of the Cauchy problem (3) for equation (1) which can be represented as: $u(t)=U_{0}^{t} u_{0}+U_{1}^{t} u_{1}$.

Example 3. Let $\mathfrak{U}=\ell_{q}^{m+2}, \mathfrak{F}=\ell_{q}^{m}, m \in \mathbb{R}, q \in(0,1)$, where $\ell_{q}^{m}$ is a quasi-Sobolev space defined in example 1 , and $A, B_{1}, B_{0}$ are the operators constructed in example 2.

Consider the Boussinesq-Love equation as one of the most well-known non-classical equations of mathematical physics of the second order in time [11]

$$
(\lambda-\Lambda) \ddot{u}=\alpha\left(\Lambda-\lambda^{\prime}\right) \dot{u}+\beta\left(\Lambda-\lambda^{\prime \prime}\right) u, u(t) \in \mathfrak{U} .
$$

Theorem 3. Let $\lambda \notin\left\{\lambda_{k}\right\}$ or $\left(\lambda \in\left\{\lambda_{k}\right\}\right) \wedge\left(\lambda=\lambda^{\prime}\right) \wedge\left(\lambda \neq \lambda^{\prime \prime}\right)$. Then for any sequence

$$
u_{j}=\left\{u(j k\} \in \mathfrak{U}^{1}=\left\{\begin{array}{l}
\mathfrak{U}, \text { if } \lambda \neq \lambda_{k}, k \in \mathbb{N} ; \\
\left\{u \in \mathfrak{U}: u_{l}=0, \lambda=\lambda_{l}\right\}, \quad j=0,1
\end{array}\right.\right.
$$

there exists a unique solution of (3), (4), which also has the form

$$
\begin{gathered}
u(t)=\sum^{\prime}\left[\frac{\mu_{k}^{1}\left(\lambda-\lambda_{k}\right)+\alpha\left(\lambda^{\prime}-\lambda_{k}\right)}{\left(\lambda-\lambda_{k}\right)\left(\mu_{k}^{1}-\mu_{k}^{2}\right)} e^{\mu_{k}^{1} t}+\frac{\mu_{k}^{2}\left(\lambda-\lambda_{k}\right)+\alpha\left(\lambda^{\prime}-\lambda_{k}\right)}{\left(\lambda-\lambda_{k}\right)\left(\mu_{k}^{2}-\mu_{k}^{1}\right)} e^{\mu_{k}^{2} t}\right] u_{0 k} e_{k}+ \\
+\sum \frac{e^{\mu_{k}^{1} t}-e^{\mu_{k}^{2} t}}{\left(\mu_{k}^{1}-\mu_{k}^{2}\right)} u_{1 k} e_{k},
\end{gathered}
$$

where the single quote at the sum means the absence of terms with numbers $k$ such that $\lambda=\lambda_{k}$. Here $\mu_{k}^{1,2}$ are the roots of $(2)$, the vectors $e_{k}=(0,0, \ldots, 0,1,0, \ldots)$, where unit stands on the $k$-th place. The set $\mathfrak{U}^{1}$ is a phase space of equation (4). 


\title{
References
}

1. Showalter R.E. The Sobolev Type Equations. I (II). Appl. Anal, 1975, vol. 5, no. 1 (2), pp. 15-22 (pp. 81-99).

2. Sviridyuk G.A., Fedorov V.E. Linear Sobolev Type Equations and Degenerate Semigroups of Operators. Utrecht, Boston, Köln, VSP, 2003. 216 p. DOI: 10.1515/9783110915501

3. Zamyshlyaeva A.A. Lineynye uravneniya sobolevskogo tipa vysokogo poryadka [Linear Sobolev Type Equations of High Order]. Chelyabinsk, Publ. Center of the South Ural State University, 2012. 107 p.

4. Shestakov A.L., Keller A.V., Nazarova E.I. Numerical Solution of the Optimal Measurement Problem. Automation and Remote Control, 2012, vol. 73, no. 1, pp. 97-104. DOI: $10.1134 /$ S0005117912010079

5. Manakova N.A., Dyl'kov A.G. Optimal Control of the Solutions of the Initial-finish Problem for the Linear Hoff Model. Mathematical Notes, 2013, vol. 94, no. 1-2, pp. 220-230. DOI: $10.1134 /$ S0001434613070225

6. Zamyshlyaeva A. A., Tsyplenkova O.N. Optimal Control of Solutions for Showalter-SidorovDirichlet Problem for the Boussinesq-Love equation. Differential equations, 2013, vol. 49, no. 11, pp. 1390-1398. DOI: 10.1134/S0012266113110049

7. Sviridyuk G.A., Keller A.V. Invariant Spaces and Dichotomies of Solutions of a Class of Linear Sobolev Type Equations. Russian Mathematics (Izvestiya VUZ. Matematika), 1997, vol. 41, no. 5, pp. 57-65.

8. Sagadeeva M.A. Dikhotomii resheniy lineynykh uravneniy sobolevskogo tipa [Dichotomy of Solutions of Linear Sobolev Type Equations]. Chelyabinsk, Publ. Center of the South Ural State University, 2012.

9. Berg J., Löfström J. Interpolation Spaces. An Introduction. Berlin, Heidelberg, N.Y., 1976. $222 \mathrm{p}$.

10. Sviridyuk G.A., Al Delfi D.K. Splitting Theorem in Quasi-Sobolev spaces. Matematicheskie zametki YaGU, 2013, vol. 20, no. 2, pp. 180-185. (in Russian)

11. Love A.E.H. A Treatise on the Mathematical Theory of Elasticity. N.Y., Dover Publications, 1944. $643 \mathrm{p}$.

Received September 4, 2014

УДК 517.9

DOI: $10.14529 / \operatorname{mmp} 150112$

\section{ОБ ОДНОЙ МАТЕМАТИЧЕСКОЙ МОДЕЛИ СОБОЛЕВСКОГО ТИПА В КВАЗИБАНАХОВЫХ ПРОСТРАНСТВАХ}

\author{
А.А. Замышляева, Х.М. Ал Хелли
}

Теория уравнений соболевского типа переживает эпоху бурного расцвета. В данной работе теория уравнений соболевского типа высокого порядка с относительно спектрально ограниченным пучком операторов, развитая в банаховых пространствах, переносится в квазибанаховы пространства. Мы используем уже хорошо зарекомендовавший себя при решении уравнений соболевского типа метод фазового пространства, заключающийся в редукции сингулярного уравнения к регулярному, определенному на некотором подпространстве исходного пространства. Построены пропагаторы и фазовое пространство полного уравнения соболевского типа второго порядка. Абстрактные результаты иллюстрированы конкретными примерами. В качестве приложения рассмотрено уравнение Буссинеска - Лява в квазибанаховом пространстве.

Ключевые слова: уравнения соболевского типа высокого порядка; квазибанаховы пространства; пропагаторы; фазовое пространство. 


\section{Литература}

1. Showalter, R.E. The Sobolev type equations. I (II) / R.E. Showalter // Appl. Anal. - 1975. V. 5, № 1 (2). - P. 15-22 (P. 81-99).

2. Sviridyuk, G.A. Linear Sobolev Type Equations and Degenerate Semigroups of Operators / G.A. Sviridyuk, V.E. Fedorov. - Utrecht, Boston; Köln: VSP, 2003. - 216 p.

3. Замышляева, А.А. Линейные уравнения соболевского типа высокого порядка / А.А. Замышляева. - Челябинск: Издат. центр ЮУрГУ, 2012. - 107 с.

4. Шестаков, А.Л. Численное решение задачи оптимального измерения / А.Л. Шестаков, А.В. Келлер, Е.И. Назарова // Автоматика и телемеханика. - 2012. - № 1. - С. 107-115.

5. Манакова, Н.А. Оптимальное управление решениями начально-конечной задачи для линейных уравнений соболевского типа / Н.А. Манакова, А.Г. Дыльков // Вестник ЮУрГУ. Серия: Математическое моделирование и программирование. - 2011. - № 17 (234).C. $113-114$.

6. Замышляева, А.А. Оптимальное управление решениями задачи Шоуолтера-СидороваДирихле для уравнения Буссинеска-Лява / А.А. Замышляева, О.Н. Цыпленкова // Дифференциальные уравнения. - 2013. - Т. 49, № 11. - С. 1390-1398.

7. Свиридюк, Г.А. Инвариантные пространства и дихотомии решений одного класса уравнений типа Соболева / Г.А. Свиридюк, А.В. Келлер // Известия высших учебных заведений. Математика. - 1997. - №5. - С. 60-68.

8. Сагадеева, М.А. Дихотомии решений линейных уравнений соболевского типа / М.А. Сагадеева. - Челябинск: Издат. центр ЮУрГУ, 2012. - 139 с.

9. Берг, Й. Интерполяционные пространства. Введение / Й. Берг, Й. Лефстрем - М.: Мир, 1980. $264 \mathrm{c}$.

10. Свиридюк, Г.А.Теорема о расщеплении в квазисоболевых пространствах / Г.А. Свиридюк, Д.К. Аль-Делфи // Математические заметки ЯГУ. - 2013. - Т. 20, № 2. С. 180-185.

11. Ляв, А. Математическая теория упругости / А. Ляв; пер. с англ. Б.В. Булгаков, В.Я. Натанзон. - Москва; Ленинград: ОНТИ, 1935. 674 с.

Алена Александровна Замышляева, кандидат физико-математических наук, доцент, кафедра «Уравнения математической физики», Южно-Уральский государственный университет (г. Челябинск, Российская Федерация), alzama@mail.ru.

Аль Хелли Хамис Монем Абдулькадум, магистрант, кафедра «Уравнения математической физики», Южно-Уральский государственный университет (г. Челябинск, Российская Федерация).

Поступила в редакцию 4 сентября 2014 2. 